\title{
Catalogue of the genus Cereopsius Pascoe 1857 (Coleoptera: Cerambycidae: Lamiinae) in the Philippines with description of a new species from Mindanao
}

\author{
MILTON NORMAN MEDINA ${ }^{1 *}$, LESLAE KAY MANTILLA ${ }^{1,3}$, ANALYN CABRAS $^{1,4} \&$ FRANCESCO VITALI $^{2}$ \\ ${ }^{1}$ Coleoptera Research Center, Institute of Biodiversity and Environment, University of Mindanao, Davao City Philippines \\ ${ }^{2}$ National Museum of Natural History, rue Munster 24, L-2160 Luxembourg, Grand-Duchy of Luxembourg \\ (1) https://orcid.org/0000-0003-3052-2910 \\ 3 ○ https://orcid.org/0000-0001-9801-5945 \\ 4 - https://orcid.org/0000-0002-0980-1651 \\ "Corresponding author. ”" mnd_medina@umindanao.edu.ph; (1) https://orcid.org/0000-0001-6858-8048
}

\begin{abstract}
The catalogue of the genus Cereopsius Pascoe 1857 fauna of the Philippines is provided, with description of a new species, C. erasmus sp. nov. from Mindanao Island. Additional taxonomic and faunistic notes on the other Philippine species are added.
\end{abstract}

Key words: Beetles, flat-faced longhorns, Lamiini, longicorn, taxonomy

\section{Introduction}

Pascoe (1857) introduced the genus Cereopsius (Lamiinae: Lamiini) for two species, C. marmoreus and C. exoletus, from Malacca and Borneo respectively. Pascoe (1862) compared the new genus to Monohammus Dejean 1835, differing in the following characters: "approximate antennae, elongate and nearly cylindrical basal joint, the terminal joint also scarcely longer than the preceding one, in the form of thorax the whole side swelling out to form the spine, which is placed behind the middle, the trigonate elytra broadest at the base, and rapidly receding towards the apex, and shorter legs".

Because of differential characters between Cereopsius and Monohammus, Pascoe (1866) transferred to Cereopsius some members of Monohammus, namely: "M. elpenor Newman”, M. quaestor Newman 1842, M. luctor Newman 1842 and M. praetorius (Erichson 1834). The said species together with C. helena White 1858, C. exoletus Pascoe 1857, C. marmoreus Pascoe 1857, C. patronus (Pascoe 1859) and C. histrio (Pascoe 1859) brings a total of 8 species.

Later, Pascoe (1866) separated C. helena and C. histrio by introducing the genera Etymestia Pascoe, 1866 and Othelais Pascoe, 1866, respectively. Breuning (1944a) synonymised Etymestia with Cereopsius, while Othelais has remained as a separate genus until now.

Heller (1915) added a new species, C. irregularis, which Schultze (1916) and Aurivillius (1922) cited together with the three previously mentioned species but which Breuning (1944c) transferred to Blepephaeus Pascoe 1866. Breuning (1974, 1980, 1981) and Hüdepohl (1993) added four new species for Philippines: C. spilotoides Breuning 1974, C. mimospilotus Breuning 1980, C. vivesi Breuning 1981 and C. copei Hüdepohl 1993. At present, there are 32 species of Cereopsius worldwide and seven of which are found in the Philippines. This paper presents a recent catalogue of the genus Cereopsius in the Philippines and the description of a new species from Mindanao Island. 


\section{Materials and methods}

Materials used for describing the new species were obtained during the 2019 Erasmus+ Mobility Programme and University of Mindanao Research (UMCRC) and Publication Center field explorations. Data of other paratypes come from the collections mentioned afterwards.

The specimens at the UMCRC were collected using handpicking and hand netting and killed using ethyl acetate. Morphological characters were observed under Luxeo 4D and Nikon SMZ745T stereomicroscopes. Habitus images were taken with Canon EOS 6D digital camera equipped with MP-E macro lens. All images were then stacked using Helicon Focus and processed using a licensed version of the software Photoshop CS6Portable.

Measurements of various body parts follows Yoshitake and Yamasako (2016) with slight modification on the body length: $\mathrm{LB}=$ length of the body, from the antennal support to the apices of clothed elytra; $\mathrm{WH}=$ maximum width across the head, from the outer margin of a gena to that of another; $L G=$ length of the gena, from the upper margin to the lower margin; $\mathrm{LL}=$ length of the lower eye lobe, from the upper margin to the lower margin; $\mathrm{WL}=$ maximum width across width of the lower eye lobe; LP = length of the pronotum, from the base to apex along the midline; $\mathrm{WP}=$ maximum width across the pronotum; $\mathrm{LE}=$ length of the elytra, from the level of the basal margins to the apices of the clothed elytra; $\mathrm{WEH}=$ width of the elytra at humeri. All measurements are given in millimetres.

Type materials are deposited in the following collections:

BSC Ben Sale collection, Stevenage, Hertfordshire, United Kingdom

FVC Francesco Vitali Collection, Luxembourg, Grand-Duchy of Luxembourg

GCC Gerard Chemin, Champigny-sur-Marne, Collection, France

MNHNL National Museum of Natural History, Luxembourg, Grand-Duchy of Luxembourg

UMCRC University of Mindanao Coleoptera Research Center

\section{Catalogue}

\section{Subfamily Lamiinae}

\section{Tribe Lamiini}

Ceropsius Pascoe, 1862

Type-species: Cereopsius exoletus Pascoe 1857 (Breuning's fixation, 1944a)

\section{Cereopsius copei Hüdepohl 1993}

Entomofauna, Zeitschrift für Entomologie, 14 (19): 325.

Distribution: Philippines: Palawan (Mt. Pagoy)

Type deposition: HOLOTYPE ( + _ —Zoologische Staatssammlung des Bayerischen Staates, München Scientific synonym: None.

\section{Cereopsius luctor (Newman 1842)}

Monohammus luctor Newman 1842. The Entomologist, 17: 276.

Distribution: Philippines: Luzon (Manila), Leyte*, Mindanao (Bukidnon, Surigao del Sur*)

Type deposition: HOLOTYPE $(\widehat{\delta})$-The Natural History Museum, London

Unavailable names: Cereopsius luctor m. reductus Breuning 1944 


\section{Cereopsius mimospilotus Breuning 1980}

Mitteilungen aus dem Zoologischen Museum in Berlin 56 (2): 172.

Distribution: Philippines: Mindanao (Bukidnon, Zamboanga del Norte*)

Type deposition: HOLOTYPE $\left(\delta^{\Uparrow}\right)$-National Museum of Natural History, Paris.

Scientific synonym: Cereopsius cabigasi Vives 2005

Note. Vives (2005) described Cereopsius cabigasi indicating a relation with $C$. luctor due to the elytral pattern. In reality, this taxon can show four to six elytral spots (six in C. luctor), a scape apically enlarged (conical in C. luctor), a more or less yellowish pubescence (pure white in $C$. luctor) and a variable pronotal band of pubescence. The examination of genitalia revealed that $C$. mimospilotus is actually very closely related to $C$. quaestor, from which it differs in the reddish unicolor antennae (black and with antennomere 5 ringed of white pubescence in $C$. quastor). Nonetheless, some male specimens with bicolour antennae and females with indistinct white antennomeres call into question the validity of this taxon.

\section{Cereopsius praetorius (Erichson 1834)}

Lamia praetoria Erichson 1842. Nova Acta Physico-Medica Academiae Caesareae-Leopoldino-Carolinae Naturae Curiosorum 16: 268.

Distribution: Philippines: Luzon (Manila, Mont Isorog, Ifugao*, Nueva Vizcaya*), Palillo, Catanduanes, Negros*, Camiguin*; Taiwan (Orchid I.)

Type deposition: HOLOTYPE ( $($ ) _-Museum for Naturkunde-Leibniz Institute for Evolution and Biodiversity Science, Berlin; SYNTYPE—The Natural History Museum, London

Scientific synonym: Cereopsius shamankariyali Kano 1939

Unavailable names: Cereopsius praetorius m. transitivus Breuning 1944; Cereopsius praetorius m. flavescens Breuning 1944; Cereopsius praetorius m. elpenor Breuning 1944.

Note: "Monochamus elpenor Newman" was a nomen nudum of the collection of the British Museum, which Pascoe (1862) cited for the first time. Thomson (1864) mentioned it as type-species of Cereopsius and Aurivillius (1922) considered it as an aberration of C. praetorius; nonetheless, nobody described or figured this taxon. Finally, Breuning (1944a) identified it with a light form of $C$. pretorius, giving a description but without indicating a type or a typical locality. This taxon must be attributed to Breuning but, being described as a morph, it is infrasubspecific and unavailable according to the ICZN 45.6.1.

\section{Cereopsius quaestor (Newman 1842)}

Monohammus quaestor Newman 1842. The Entomologist, 17: 276.

Distribution: Philippines: Luzon (Manila); Leyte*, Mindanao (Siargao, Agusan del Norte, Lanao del Sur*); Indonesia? (Maluku: Buru, Ambon, Ceram, Halmahera)

Type deposition: HOLOTYPE (ठ゚)—The Natural History Museum, London; SYNTYPE- The National Museum of Natural History, Paris

Scientific synonyms: ?Cereopsius luctuosus Pascoe 1866; ?Cereopsius tricinctus Pascoe 1866; Cereopsius praetorius nigrobasalis Kriesche 1928; Cereopsius questor var. connecta Fisher 1934.

Unavailable names: Cereopsius quaestor m. confluens Breuning 1944; Cereopsius quaestor m. reductemaculatus Breuning 1980.

Note. The Moluccan $C$. luctuosus and $C$. tricinctus show white pubescence, while the female syntype of $C$. luctuosus does not show ringed antennomere 5 . Both characters make these taxa more closely related to $C$. mimospilotus; thus, a closer examination of the Moluccan populations is necessary to revaluate the taxonomy of these species. 


\section{Cereopsius spilotoides Breuning 1974}

Revue Suisse de Zoologie 81 (1): 74.

Distribution: Philippines: Luzon (Manila)

Type deposition: HOLOTYPE—National Museum of Natural History, Paris

Scientific synonym: None.

\section{Cereopsius vivesi Breuning 1981}

Nouvelle Revue d 'Entomologie, Paris 11 (1): 75

Distribution: Philippines: Visayas, Leyte, Marinduque.

Type deposition: HOLOTYPE $(q)$ _Eduard Vives Collection, Terrassa, Spain

Scientific synonym: None.

\section{Cereopsius erasmus sp. nov.}

Fig. 1-2.

Type material. Holotype, male (Fig. 1): PHILIPPINES_-Mindanao / Davao del Sur / Davao City / Catigan / VI.2019 / local collector (UMCRC), printed on red card.

Paratypes. 1 male: PHILIPPINES_-Mindanao / Davao del Sur / Davao City / IX.2019 / local collector (UMCRC), printed in red card. 1 male: PHILIPPINES-Mindanao / South Cotabato / T'Boli / Lake Holon / X.2019 / local collector (UMCRC), printed in red card. 1 female: PHILIPPINES-Mindanao / Davao del Sur / Davao City / Marilog District / VII.2019 / coll. local collector (UMCRC), printed in red card. 1 male: PHILIPPINES-Mindanao / Davao del Sur / Mt. Apo / I.2014 / local collector (BSC). 1 male: PHILIPPINES-Mindanao / South Cotabato / Magpet / I.2014 / local collector (BSC). 1 male: PHILIPPINES-Mindanao / Davao del Sur / Kapatagan / local collector (GCC) 1 female: PHILIPPINES-Mindanao / Davao del Sur / Kapatagan / X.2018 / local collector (FVC).

Description. Measurements: Male ( $\mathrm{n}=2)$, LB: 19.6-20.0 mm. WH: 3.1 mm. LG: $3.0 \mathrm{~mm}$. LL: 1.5 mm. WL: $0.9 \mathrm{~mm}$. LP: $3.4 \mathrm{~mm}$. WP: $6.3 \mathrm{~mm}$. LE: $14.0 \mathrm{~mm}$. WEH: 7.8mm. Female (n=2), LB: 22.0-25.0 mm. WH: 3.2-3.7 mm. LG: 3.0 mm. LL: 1.5-2.0 mm. WL: 1.0 mm. LP: 3.4-4.0mm. WP: 6.9 mm. LE: 14.4-16.5 mm. WEH: 8.0-8.1 $\mathrm{mm}$.

Adult male. Teguments lustrous black, covered with minute recumbent whitish grey pubescence; elytra with two marginal large elliptical spots of white pubescence (one pre-median and another post-median), which do not reach the elytral disc, and a wide sutural band of white pubescence on the apical third; antennomeres 3-5 widely ringed with white pubescence at base.

Head with some erect setae on the vertex. Antennae almost twice as long as body (antennomere 5 overpasses the elytral apex); scape thin, conical, abruptly enlarged at apex, covered with dense coarse punctures and semi-erect black setae; antennomeres 2-11 covered with minute greyish pubescence.

Prothorax transverse; basal and apical margin lined with whitish pubescence; disc depressed, crossed by two deep furrows, the apical one bowed posteriorly; sides with a prominent lateral spine. Scutellum triangular, widely rounded at apex and covered with minute greyish pubescence. Elytra tapered, finely punctate, with a coarse granulation near the base and a basal ridge relaxing towards the centre; apex transversely truncate and sparsely covered with sub-erect black hairs.

Coxae, trochanters and femora densely covered with minute greyish pubescence; tibiae covered with minute greyish pubescence, white and dense medially, and some semi-erect black setae; tarsi covered with dense whitish pubescence and some semi-erect black setae. Propleuron and prosternum covered with minute greyish pubescence; procoxal cavities close posteriorly; mesocoxal cavities close; mesosternum, mesepisternum and metepisternum covered with greyish pubescence at the sides; metasternum glabrous in the middle, with white pubescence weakly denser on the basal part; abdominal sternites with white pubescence denser at the sides; pygidium widely truncate at apex. 

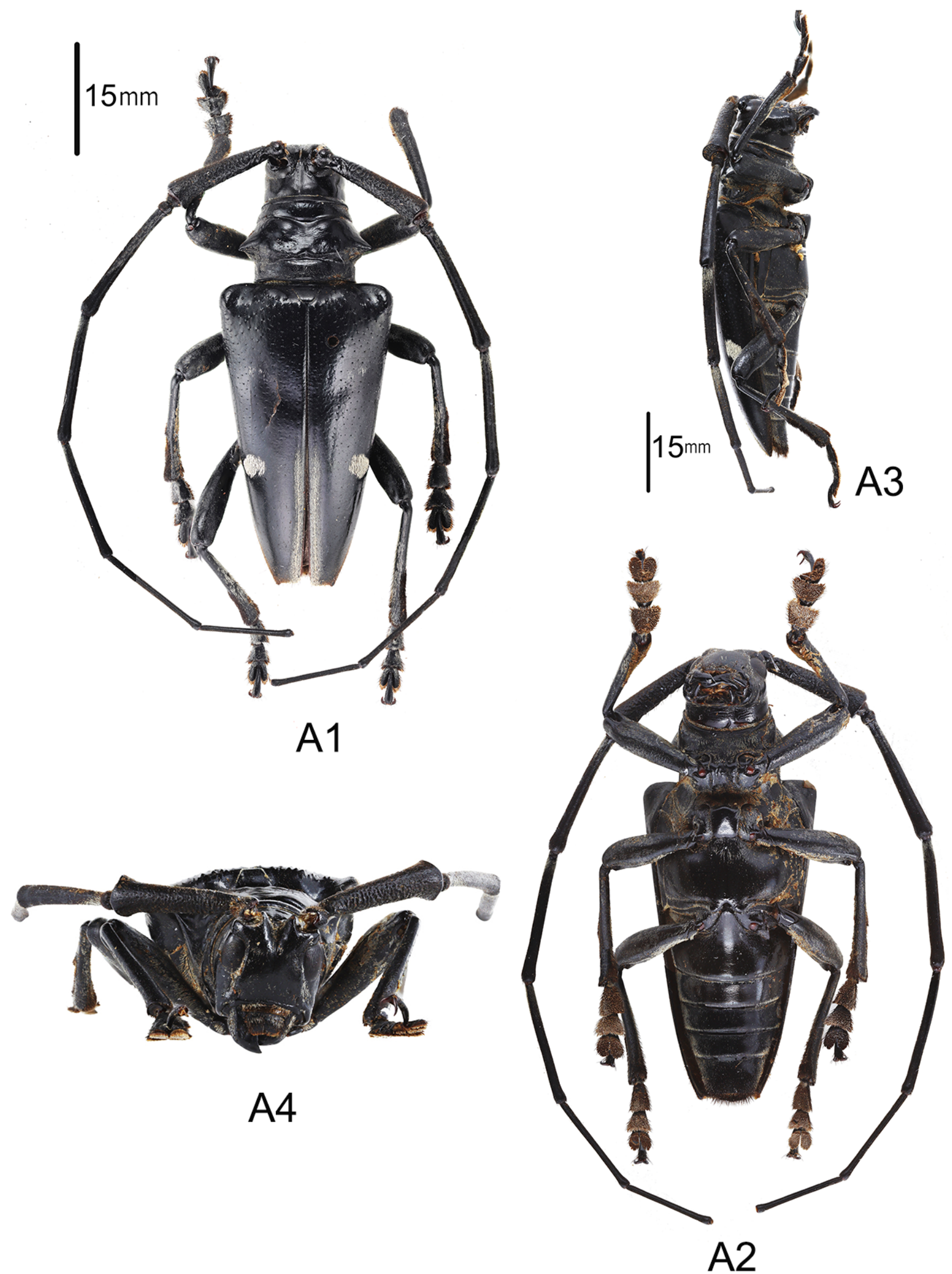

FIGURE 1a-d. Habitus of holotype (male) of Cereopsius erasmus sp. nov. a. dorsal view, b. ventral view, c. lateral view, d. frons 

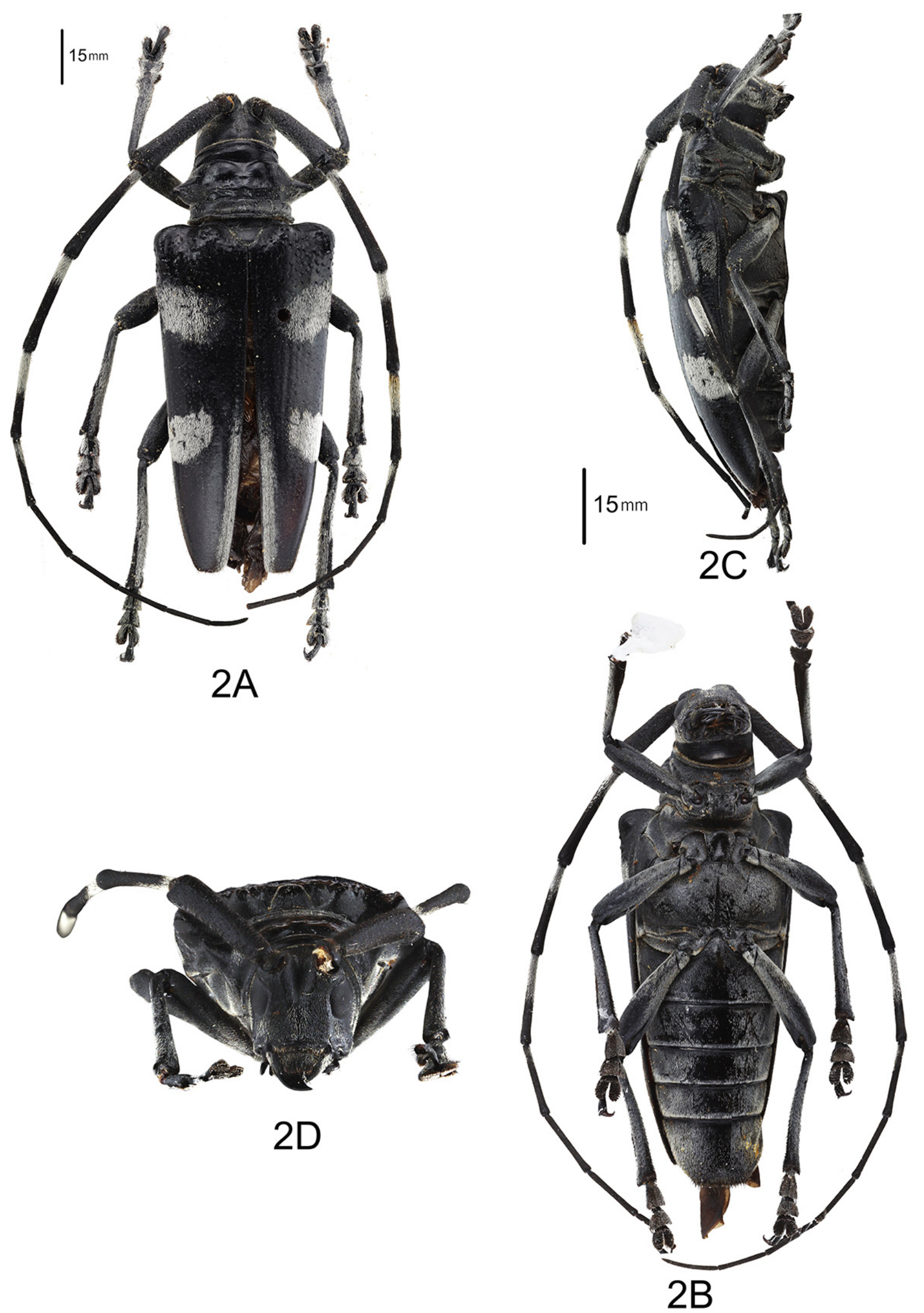

FIGURE 2a-d. Female habitus of Cereopsius erasmus sp. nov. A. dorsal view, B. ventral view, C. lateral view, D. frons 


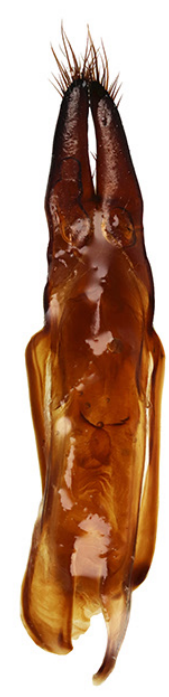

A

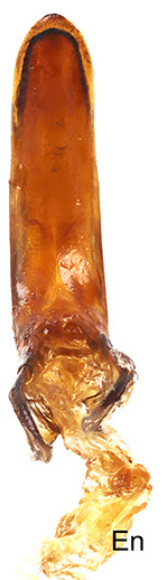

D

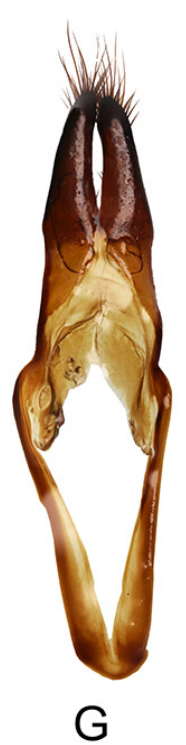

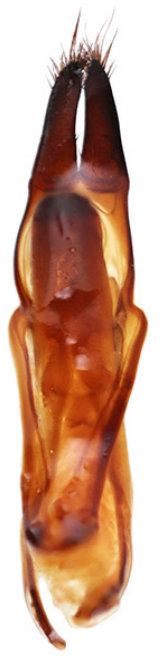

B

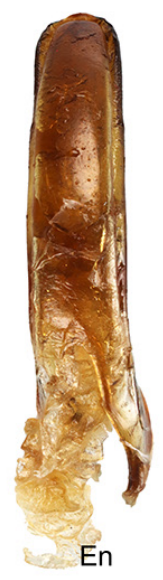

$E$

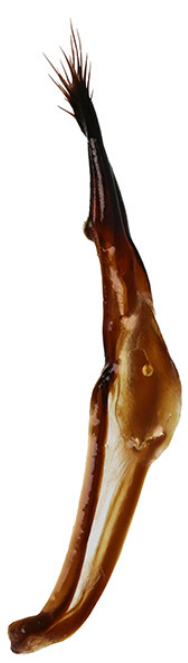

$\mathrm{H}$

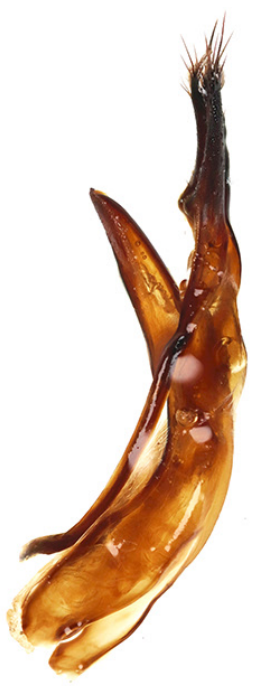

C

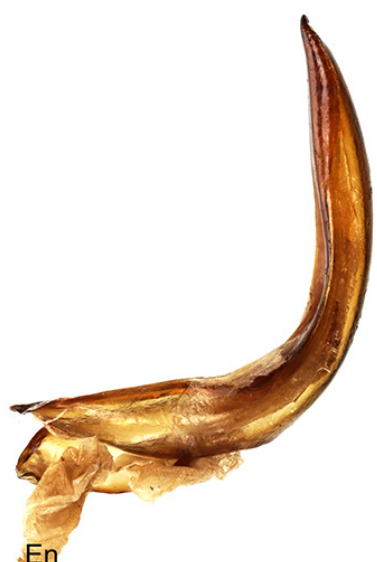

$\mathrm{F}$

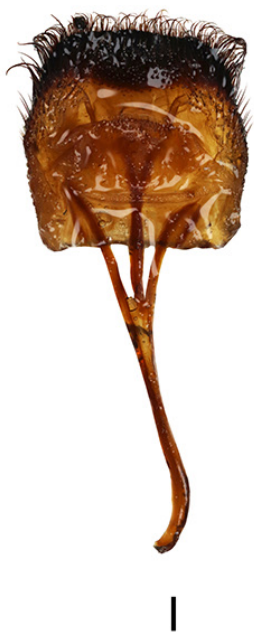

FIGURE 3A-I. Genitalia of Cereopsius erasmus sp. nov. A. ventral view of aedeagus and tegmen, B. dorsal view of aedeagus and tegmen, C. lateral view of aedeagus and tegmen, D. ventral view of aedeagus, E. dorsal view of aedeagus, F. lateral view of aedeagus, G. ventral view of tegmen, H. lateral view of tegmen, I. genital segment, En-Endophallus. 
Male genitalia (Fig. 3A-H): Tegmen about $3.8 \mathrm{~mm}$ long; lateral lobes slender, about $1.0 \mathrm{~mm}$ long and $0.5 \mathrm{~mm}$ wide; base with a slightly recurved ridge bearing fine setae; apex bearing numerous setae, about $0.2-0.5 \mathrm{~mm}$ long (Fig. 3G-H). Aedeagus about $3.3 \mathrm{~mm}$ long and $0.6 \mathrm{~mm}$ wide, strongly recurved (forming an approximately right angle in lateral view) and widely rounded at apex. Tergite VIII (Fig. 3D-F) testaceous, black at apex, about as broad as long (about $1.8 \mathrm{~mm}$ ); apex truncate and covered with dense black setae, a little longer at the sides; sternite VIII entirely testaceous, widely rounded and setaceous at the lateral margin; spiculum gastrale longer than tergite VIII (about $2.8 \mathrm{~mm}$ long).

Adult female. Morphologically similar to the male, except for the much larger and taller body size, the antennae one-half longer than body (antennomere 5 reaches the elytral apex) (Fig. 2).

Differential diagnosis. Cereopsius erasmus sp. nov. belongs to the group of species with the elytral suture covered with dense pubescence. C. arbiter Pascoe 1885 differs from it in the stouter habitus, the whitish pronotal base and the white spots of pubescence located on the elytral apex and at the apical angles of the pronotum. $C$. sexmaculatus Aurivillius 1907 differs in the reddish brown teguments, the yellowish pattern and a yellowish spot of pubescence at the apical angles of the pronotum. C. niassensis Lansberge 1883 differs in the dull teguments, the shorter scape, the antennae without whitish pubescence and the thick band of pubescence traversing the elytral third. C. kulzeri Breuning 1936 differs in the dull teguments, the antennae without whitish pubescence and the elytral markings thinly connected along the suture.

Etymology. Cereopsisus erasmus sp. nov. is named after "Erasmus", acronym of the EuRopean community Action Scheme for the Mobility of University Students. This programme, which supports education, training and international linkages, is instrumental in establishing the Coleoptera Research Center (CRC) of the Philippines.

Distribution. Philippines: Mindanao (Davao del Sur; Davao City; Magpet South Cotabato; Lake Holon T'boli South Cotabato).

\section{Acknowledgements}

We are grateful to Dr. Guillermo P. Torres Jr., president of the University of Mindanao, for the establishing the Coleoptera Research Center; Mr. Gérard Chemin (Champigny-sur-Marne, France) and Mr. Ben Sale (Stevenage, United Kingdom), for the additional materials; Dr. Arvids Barševskis (Daugavpils, University in Latvia), Chrestine Torrejos (CRC) and Mark John Pepito (CRC) for the kind collaboration. Our gratitude to Dr. Francisco Nascimento for facilitating this work. The present publication is financed by the Museum of Natural History, Luxembourg.

\section{References}

Aurivillius, C. (1922) Cerambycidae: Lamiinae. Coleopterorum Catalogus, 73, 114-115.

Breuning, S. (1944a) Études sur les Lamiaires (Coleop. Cerambycidæ). Douzième tribe: Agniini Thomson. Novitates Entomologicae, 3e Supplément (115), 345-352.

Breuning, S. (1944b) Études sur les Lamiaires (Coleop. Cerambycidæ). Douzième tribe: Agniini Thomson. Novitates Entomologicae, 3e Supplément (116), 353-360.

Breuning, S. (1944c) Études sur les Lamiaires (Coleop. Cerambycidæ). Douzième tribe: Agniini Thomson. Novitates Entomologicae, 3e Supplément (117), 361-68.

Breuning, S. (1961) Catalogue des Lamiaires du Monde. Verlag des Museums G. Frey, Tutzing bei München, 5, $287-382$.

Breuning, S. (1974) Quelques nouvelles espèces de Lamiinae du Muséum d'Histoire naturelle de Genève (Coleoptera, Cerambycidae) I. Revue Suisse de Zoologie, 81 (1), 73-75. https://doi.org/10.5962/bhl.part.75991

Breuning, S. (1980) Description de nouvelles espèces de Lamiaires des Philippines (Coleoptera, Cerambycidae). Mitteilungen aus dem Zoologischen Museum in Berlin, 56 (2), 157-182.

Breuning, S. (1981) Nouvelles espèces de Lamiinae (Col. Cerambycidae) de la coll. Vives. Nouvelle Revue d 'Entomologie, 11 (1), 73-75.

Chemin, G. \& Vives, E. (2017) Etude et commentaires de la collection Romeo Lumawig des Philippines du Muséum National d'Histoire Naturelle de Paris (Coleoptera, Cerambycidae, Lamiinae). Les Cahiers Magellanes, New Series, 25, 8-28.

Erichson, W.F. (1834) Coleoptera und Lepidoptera. In Meyen's, Beiträge zur Zoologie, gesammelt auf einer Reise um die Erde, und W. Erichsons and H. Burmeisters und Abbildungen der auf dieser Reise gesammelten Insekten. Nova Acta PhysicoMedica Academiae Caesareae-Leopoldino-Carolinae Naturae Curiosorum, 16 (Supplement 1), 219-284. 
Gemminger, M. \& von Harold, E. (1873) Catalogus coleopterorum hucusque descriptorum synonymicus et systematicus. $M u$ nich, 10, 2989-3232, index.

Heller, K.M. (1915) Neue Käfer von den Philippinen: III. The Philippine Journal of Science, 10 (4), Section D $219-249$.

Hüdepohl, K.E. (1993) Über südostasiatische Cerambyciden XI (Coleoptera, Cerambycidae). Entomofauna, Zeitschrift für Entomologie, 14 (19), 321-327.

Newman, E. (1842) Cerambycitum Insularum Manillarum Dom. Cuming captorum enumeratio digesta. The Entomologist, 17, $275-277$.

Pascoe, F. P. (1857) On new genera and species of longicorn Coleoptera. Part II. The Transactions of the Entomological Society of London, Series 2, 4 (3-4), 89-112. https://doi.org/10.1111/j.1365-2311.1857.tb01817.x

Pascoe, F.P. (1862) Notices of new or little-known genera and species of Coleoptera. Part III. The Journal of Entomology descriptive and geographical, 1 (5), 319-370.

Pascoe, F.P. (1866) Longicornia Malayana; or, a descriptive catalogue of the species of the three Longicorn Families Lamiidae, Cerambycidae and Prionidae collected by Mr. A. R. Wallace in the Malay Archipelago. The Transactions of the Entomological Society of London, 3 (3), 3, 237-240.

Thomson, J. (1864) Systema Cerambycidarum ou exposé de tous les genres compris dans la famille des Cérambycides et familles limitrophes. Mémoires de la Société Royale des Sciences de Liège, 19, 1-540. https://doi.org/10.5962/bhl.title.82379

Vives, E. (2005) New or interesting Cerambycidae from Philippines (Part I) (Coleoptera, Cerambycidae). Les Cahiers Magellanes, 49, 1-13. 